\title{
Universiteit
}

Leiden

The Netherlands

\section{Gloves in times of AIDS: Pentecostalism, Hair and Social Distancing in Botswana}

Dijk, R.A. van; Becker F. Geizzler P.W.

\section{Citation}

Dijk, R. A. van. (2009). Gloves in times of AIDS: Pentecostalism, Hair and Social Distancing in Botswana. In Studies of religion in Africa (pp. 283-306). Leiden, Boston: Brill. Retrieved from https://hdl.handle.net/1887/20401

Version: $\quad$ Not Applicable (or Unknown)

License: $\quad$ Leiden University Non-exclusive license

Downloaded from: https://hdl.handle.net/1887/20401

Note: To cite this publication please use the final published version (if applicable). 


\title{
GLOVES IN TIMES OF AIDS: PENTECOSTALISM, HAIR AND SOCIAL DISTANCING IN BOTSWANA
}

\author{
Rijk van Dijk
}

\section{Introduction}

Pentecostalism, an increasingly popular form of Christianity in parts of Africa, is marked by the sense of spiritual superiority it fosters among its adherents through an ideological emphasis on 'breaking' (Meyer 1998, 2004, Van Dijk 1997, Robbins 2004, 2007, Engelke 2004). As this literature demonstrates, the creation of a rupture with the past, traditions, social relations and nation-state projects is at the heart of much of the Pentecostal ideology. It appears to inform Pentecostal religious practices as leaders and groups have quickly become popular through their proclaimed access to superior powers to heal and to provide deliverance from ancestral curses and demons. This inspires the pursuit of a 'breakthrough' in personal or social circumstances to gain progress and prosperity (Maxwell 1998, Meyer 2002, Akoko 2004, Gifford 2004, Hasu 2006). The healing practices of traditional healers, the worship of the mainstream and former missionary churches, or the cultural policies of African nation-states are declared as spiritually inferior, superstitious and backward in many Pentecostal public messages. With the arrival of HIV/AIDS, the Pentecostal project of demonstrating spiritual superiority in creating a rupture was in many cases continued by leaders claiming to be able to deal with, or even cure, the disease. Adherence to a born-again style of life is often promoted as the only effective protection (Garner 2000, Mate 2002, Pfeiffer 2004, Dilger 2007, Prince 2007).

The notion of Pentecostal spiritual superiority is linked to the moral project of 'maturing in the faith' as some Pentecostal leaders in Ghana would call it, or kukhwima, 'ripening', as the born again Pentecostals in Malawi say (see Van Dijk 1998). This is the process of attaining a different and superior moral status that conversion or being born again entails. The superiority achieved by conversion is one reason why in many Pentecostal circles young people can wield moral authority over 
people even if the latter are more senior in age than the Pentecostal preacher or leader (see Van Dijk 1992).

As Joel Robbins (2007) has been arguing, the Pentecostal ideological emphasis on rupture, on a complete break with the person's former life, is experienced by members as an important aspect of their identity. In his view, anthropology has a tendency to explain away this existential importance of rupture and break as it commonly stresses cultural continuities instead. While he argues for an anthropology that is engaged with understanding ruptures and break, the question remains unanswered as to how the Pentecostal pursuit of discontinuity is translated into actual praxis. To what extent can this spiritual and moral project embedded in Pentecostal thinking - 'being above the ordinary things' as Ghanaian Pentecostals explained - be realised by Pentecostals in everyday situations?

This contribution aims to demonstrate that while rupturing and 'breaking' are part of the overall ideology, they are in practice translated in day-to-day situations in patterns of social distancing. Pentecostalism can be regarded as a 'this-worldly' religion (see Martin 1990), focused on the immanent aspects of life and concerned with progress and prosperity, while it simultaneously maintains a practical emphasis on keeping a certain distance from everyday life. This dialectic can be noticed in the way Pentecostals in Ghana deal with the issue of the gift. They commonly distrust and reject reciprocal relations outside Pentecostal circles as they find it hard to control the spiritual powers that gift-exchange may entail. At the same time, they encourage gift relations within their circles as signs of trustworthiness and spiritual control (Van Dijk 2002, 2005, Coleman 2004, Akoko 2004). There are many situations in which this dialectic of distancing, keeping relations at bay, controlling, supervising and rearranging exchanges take place. These include important moments in individual lives where births, marriages, funerals, sickness and misfortune are concerned. In all such situations there is the deliberate creation of a distance that allows for a critical reflection of how things should be done, as distinct from custom or social expectations and obligations. There is a sense of a higher spiritual and moral ground from which customary social arrangements can be perceived, evaluated, accepted or rejected.

This notion of social distancing is relevant in understanding the way Pentecostalism has become connected to class and is particularly significant for the way Pentecostalism relates to the creation of status, prestige, style and authority for the emerging urban, entrepreneurial 
middle classes (Maxwell 1998, Meyer 2002, De Witte 2008, MarshallFratani 2000, Van Dijk 2003, Gifford 2004) and has helped these to move beyond the obligations and limitations of local relations.

This chapter explores this dimension of Pentecostalism in the Ghanaian immigrant community in Botswana. Issues of social distancing as a particular translation and negotiation of the ideological imperative of 'breaking' are relevant here through the ways in which these churches became connected to a business class of Ghanaian female entrepreneurs who operate hair salons in the country's major towns. This practice of social distancing gained pertinence because of the AIDS pandemic, which has special significance for that type of small business activity. Both in relation to class formation and the AIDS scare, Pentecostal notions of spiritual and moral superiority shape identities and social relations. More specifically, these issues can be seen to surface in the use of certain objects and resources. In the context of Ghanaian-owned hair salons and the position of the Ghanaian owners/business women, the use and non-use, presence or absence of rubber gloves has become a specific marker of the different class positions and their ideological framing and legitimacy. In the context of the Ghanaian hair salons, the glove became an index of work and power relations related to the Pentecostal faith and the AIDS crisis. Studying this object (the glove) allows us to see how ideas of social distancing and superiority translate into actual behaviour. This focus turns the process of how notions of rupture and 'breaking' inform specific distancing practices open to anthropological scrutiny.

\section{The presence or absence of gloves}

In studying the implications of the Pentecostal ideology on spiritual and moral superiority, some literature has focused on how the ideology 're-tunes' people's sensory modes (Meyer 2006: 20). It makes adherents perceive things differently, makes them aware of the (spiritual) powers that may be imbued in matters relating to the past, to custom and tradition. It makes people turn a blind eye to a range of aspects of cultural and social life, creating what could be called 'social anaesthesia'. ${ }^{1}$ This

\footnotetext{
1 The seminal article by Feldman (1994) that introduced the concept of cultural anaesthesia has been informative of the anthropology of the senses (see Seremetakis 1994, Stoller 1989) but seems to have had little impact beyond that particular field of
} 
indicates an aspect of an ideology that urges people to keep out of touch with the reality of others and no longer to see their plight. As Herzfeld (1992) argued, such social construction of indifference may lead to practices whereby people become far removed from everyday human face-to-face contact and thus lose a direct engagement with other people's predicament.

Social anaesthesia can inform or reaffirm class positions by ideological sensitivities and insensitivities, by specific notions of what it is preferable to see, hear and touch and what not (Asad 1993, Chidester 1992, 2005, Verrips 2006). On the one hand, religious forms such as Pentecostalism may foster ideas regarding the social classes that have become involved in its circles of activity; on the other, these social classes translate these ideas of social distancing into everyday social practices (see for an example in Nigeria, Smith 2001). In this contribution, I explore a kind of Verdichtung, a kind of condensation of such ideas and practices in situations revolving around just one single subject: the use of gloves.

Consider the case of Kofi (a fictive name), a hairdresser from Ghana who in 2003 worked in one of the many Ghanaian-owned hair salons in Gaborone, the capital of Botswana. As I described in an earlier article (Van Dijk 2007), when I met him he was complaining bitterly about conditions at his place of work. Being in contact with Batswana (native inhabitants of Botswana, plural of Motswana) on a daily basis and working in one of the poorer parts of this otherwise prosperous city, he was increasingly unsettled about the fact that his shop did not have a sterilising machine. In view of the country's current HIV rate, the use of scissors, blades, needles and other sharp objects and utensils is problematic to every hairdresser. Sterilising machines have been introduced into the hairdressing sector in Botswana and most salons that attract middle-class customers have one, offering protection to customers and staff alike. Some salons even advertise the fact that they own such machines on their road-side banners and posters. The costs of such appliances are not large, but in the poorer areas they are often absent.

study. The problematic of the perspective opened up by Feldman is an assumption of culture in an almost essentialised understanding of the term. Cultural difference in his view is also lodged in the ways culture makes people unable to feel, to be nonempathetic towards the pain and suffering of the other. In his study of the Rodney King case, this means that, in his view, the white middle-class is marked by a primordial and culturally based insensitivity towards the plight and predicaments of their fellow Afro-American citizens. 
His complaint was stronger, and perhaps more desperate, when it came to the absence of gloves. In the view of many in the hair business, it is obviously vital to use gloves when flesh-to-flesh contact is unavoidable and when the use of sharp objects warrant the use of protective devices. In addition to the sharp utensils, the use of toxic chemicals, which as many hairdressers say 'make the skin of the fingers run thin', makes wearing gloves even more important. Rubber, or so-called surgical, gloves, have been introduced in various sectors in society, even comprising the practices of traditional healers (dingaka) where one can now expect to find boxes of gloves. These are to be used when incisions are made on the skin of the client with razor-blades. When these incisions bleed, medicines are rubbed into them.

Yet, despite the importance and popularity of the glove, and even more so despite his pleading to be given gloves to use, the Ghanaian owner of the shop did not provide them, Kofi explained. Their absence was indeed remarkable and indicated an important level of inequality between the worker, unable to afford relatively inexpensive gloves, and the female owner. A year later he died, and although the autopsy report was not circulated within the Ghanaian community, many of his co-workers suspected it had been an AIDS-related death (leaving open whether the absence of protective devices was to be considered as the main cause of death).

This situation of gloves becoming central in the protection against HIV/AIDS as well as in the case of the hairdressers and the marking of class differences between owners and their workers is replicated in many situations. Another male hairdresser, Joseph (also a fictive name), who worked in one of the Ghanaian-owned hair salons in the Mogoditshane suburb, explained how his use of gloves was again and again curtailed by the 'madam'. Using a number of sets of gloves during the different stages of doing hair (rinsing, 'relaxing' i.e. the application of chemicals, cutting and shaving), he was told not to 'empty a box' (meaning a box containing 100 rubber gloves) unless he was going to pay for them himself. While complaining that the 'owner never touches a scalp herself' (i.e. excluding herself from being exposed to dangers), he said that he had no other option than to 'use the powder', which is the washing powder he applies to be able to use the same set of gloves over and over again. 'After using the powder, I simply hang them to dry a bit in the wind, I will not buy them myself!!'

Confirming that he knew about the risks involved (not only the gloves still being infected even after the use of 'powder', but also the glove 
becoming worn out and therefore likely to tear or develop holes), he blamed the owner for not 'taking care of the staff properly' irrespective of the fact that the owner had attended one of the Hairdressers-ofthe-World-against-AIDS (a L'Oreal-sponsored information campaign) workshops that was held in this area some time ago. Some of the hair salons in Mogoditshane were still displaying the advertisements and posters that had been handed out during the awareness-raising campaign, the poster signalling the message 'Your Hairdresser Cares' and spelling out all the preventative steps that should be taken to make sure hygienic measures are in place. ${ }^{2}$ Yet the owners do generally not work their customers' scalps directly; they employ a person as a shop overseer and deliberately keep their distance from their workers. While these awareness-raising campaigns may indeed be able to convey prevention messages, from the perspective of these workers - excluded from participation in such workshops as Joseph indicated - they did not reach the persons for whom the information was relevant.

The limitation on gloves was compounded by the lack of sterilisation: although a sterilisation machine was present, it had broken down some time ago. The absence of gloves and other measures of protection such as sterilising machines are expressions of how the workers' concerns and risks can become neglected by shop owners.

The presence or absence of gloves also reflects underlying notions of the importance of touch, tactility, bodily contact and risk in the context of HIV/AIDS as much as they mark class positions. Tactile regimes in their relation to class positions may be influenced by, and changed through, economic interests and pressures, and may be reframed by religious ideologies (Geurts 2002, Taylor 1990, Geissler \& Prince 2007, De Witte 2008). In the case of these workers, why were gloves absent? Why did the owner of the shop want to control this part of the contact

${ }^{2}$ Another organisation, PSI (Population Services International), is targeting hair salons in Zimbabwe for the purpose of introducing and distributing female condoms to women. The organisation's website reads:

A novel approach used by PSI/Zimbabwe to increase awareness and distribution of the Care female condom capitalised on the relationships between Zimbabwean women and their hairdressers. PSI/Zimbabwe trained hairdressers in over 500 hair salons, which also served as retail outlets for the product. Many women in Zimbabwe visit hair salons on a regular basis and the predominately female environment of salons offer a unique setting for women to touch and feel the product and discuss issues surrounding condom use and negotiation. Over $52 \%$ of the 1.4 million condoms were sold through the hair salon network. http://www.psi .org/our_programs/products/female_condom.html. 


\section{Your Hairdresser Cares}

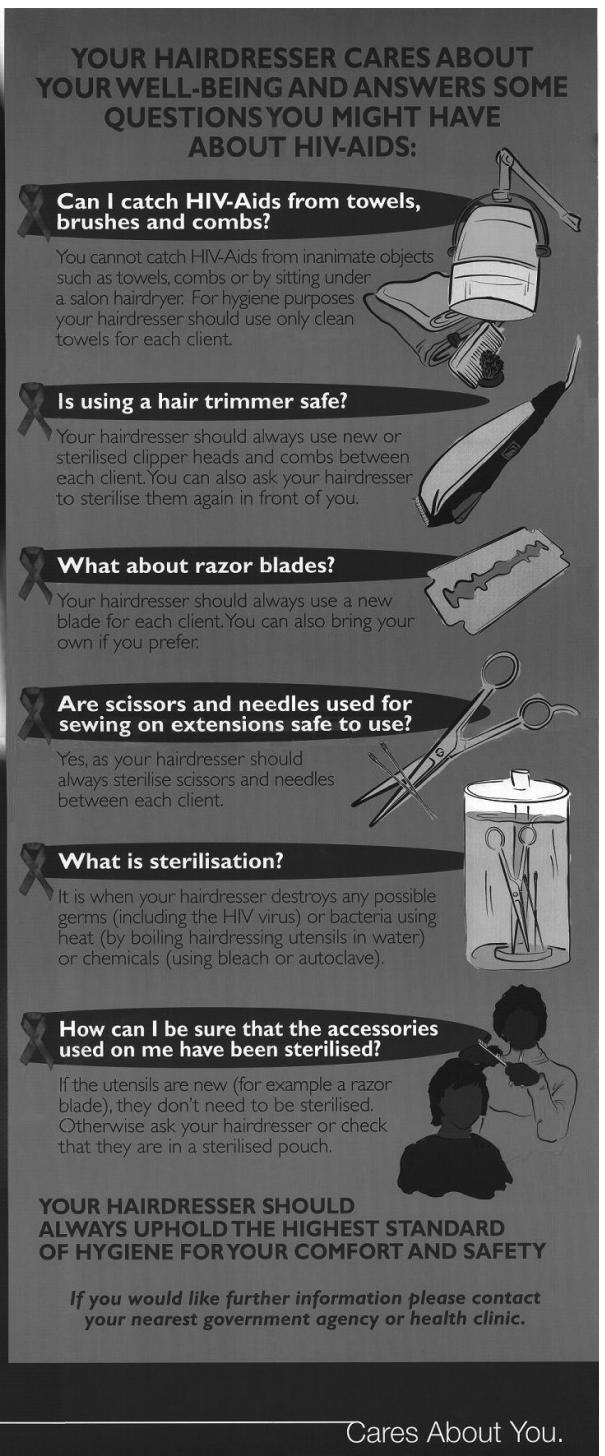

SOFTSHEEN'CARSON

PROFESSIONAL

Cares About You

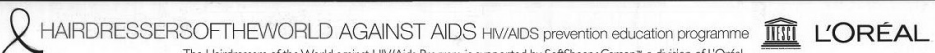
The Hairdesesers of the Wond against HIV/Aids Program is supported by SotSheen "Carson", a dvision of LOréal

Fig. 
between the hairdresser and his customers? Inexpensive as they are, why wouldn't the owners want to provide them? Why would the owner be insensitive to the needs for protection of her workers and customers? Or do owners entertain specific views concerning the wearing of gloves and what this means in terms of their doing business in a highly competitive market? What kinds of sensitivities are imbued in the use of gloves in this context? Is the glove in itself a sign of insensitivity that the owner wants to avoid as it may jeopardise relations with customers? And importantly, what is the influence of the specific form of Christianity this owner adhered to (as so many other Ghanaian owners do), namely Ghanaian Pentecostalism, in the creation and maintenance of a regime in which insensitivities are possible, morally justified, perhaps even pursued as part of its ideological project?

\section{Owners and workers in the context of Pentecostalism}

There are two things to consider regarding the issue of the gloves in our cases: one, the workers are in most cases not member of a Pentecostal church, and second Ghana was (and still is) not as HIV/AIDS-ridden as Botswana. The presence of the Ghanaian migrant community in Botswana dates from the early 1970s when the first independent Botswana government was recruiting skilled personnel from other parts of Africa to serve in its emerging civil service (Van Dijk 2003). Ghanaian men were recruited as teachers, university professors, lawyers and doctors often bringing their wives and family. As the population of Botswana is small (around 2 million), the migration of Ghanaians was relatively small scale, yet their influence on civil society has been substantial due to their specific place in the society's social hierarchy. The wives of the Ghanaian men began to open hair and beauty salons as well as clothes shops and boutiques in the mid 1970s, recruiting personnel from Ghana who were skilled in producing complicated West-African hairstyles and in West-African fashion (for unskilled labour as cleaners or 'shampoo girls', the Ghanaian owners usually recruited 'locals') (see Van Dijk 2003).

Introducing cosmopolitan yet African beauty styles to economically expanding Botswana, their enterprises proved popular and their owners joined a rapidly expanding and increasingly affluent middle-class in Botswana's larger towns (for the significance of African hairdressing in relation to globalisation and transcultural exchange, see Nyamnjoh, 
Durham \& Fokwang 2002; Weiss 2005; Erasmus 2000; Ossman 2002). Ghanaian businesswomen form a dominant and powerful group within the Ghanaian migrant community and some developed relations with Botswana elites. The Ghanaian Women's Association (Mma Kuo), formed in the early 1980s, was the precursor to the later Botswana Association of Ghanaian Nationals. In addition, this group of affluent businesswomen was crucial in the establishment of four Ghanaian transnational Pentecostal churches that found their way to Botswana in the early 1990s. Economic and spiritual interests were intertwined by the salon owners; Pentecostal pastors visited these businesses and offered prayers for their progress, prosperity and protection against witchcraft, jealousy and malign spirits (nteho or 'consecration') involving the ritual spiritual spilling of the 'blood of Jesus'.

An important issue in this relationship between the salon owners and Pentecostalism is that Ghanaian personnel hardly ever join these churches. Practical reasons might contribute to their distance from Ghanaian Pentecostalism, remarkable as it is because so many within the Ghanaian migrant community are members of one of the Ghanaian Pentecostal churches.

These practical reasons revolve first of all around their pay. Hairdressers work long hours, seven days a week, as they do not get a fixed salary (apart from a 'basic' salary of around BP 250-300 (approx. €50)). They work 'on a percentage' of what their customers pay, leaving the lion's share to the owner of the salon or the business. Hairdressers thus have to sacrifice real income if they want to attend church meetings. A second practical obstacle between Pentecostal churches and hairdressers such as Kofi or Joseph relates to the financial commitments these churches demand from their Ghanaian members (including 'tithes' of one tenth of one's net income). Moreover, members are expected to dress in expensive clothes when attending church. Hairdressers may earn too little to meet all these expectations and therefore be recorded as not being committed or not being ready to accept the authority of the pastors.

In addition, there is the acceptance of the authority of the pastor in inspecting one's moral standing in life. While the pattern of church membership between salon owners and their workers reaffirms class positions, an additional factor is that increasingly restrictive labour (socalled 'localisation') policies are allowing fewer foreigners to come and work in this relatively affluent society. Work in hair salons is 'localised', meaning that only special conditions allow foreigners to work in the 
sector. The implication of this is that workers or salon owners must make special arrangements to recruit labour from Ghana. The recruited Ghanaian hair workers will always remain 'strangers' as their permits are only renewed on a temporarily basis and easily run the risk of not being renewed at all. In cases where they lack work permits, their position will remain ambiguous, if not illegal.

Pastors are therefore usually unsure of these workers' status. Do they have 'papers'? Is their status and identity known? Is their life history known? To which social and spiritual powers have they been exposed in past experiences while still in Ghana? These are all reasons why pastors or prominent members of the Ghanaian migrant community are never eager to really associate with lower-class workers.

The pastor's authority may conflict with the authority the female salon owners wield over them. Interestingly, the owners' power can be viewed as inclusion in a kind of extended family. When recruiting workers from Ghana, the owners usually make an explicit effort to travel from Botswana to Ghana to look for suitable personnel in cities such as Accra and Kumasi. In the process of recruiting, they will talk to the families of prospective staff and negotiations often involve an exchange of gifts. This represents the idea that families entrust these young men and women into the hands of the owners and in Botswana these owners will refer to their workers from Ghana as 'my boys and girls'. When Kofi died, the owner of his hair salon was not only obliged to arrange a funeral ceremony in Gaborone that would ensure a proper 'future remembrance' as required in diasporan Ghanaian funeral practices (De Witte 2003); she was also obliged to travel to Ghana to visit the family, present gifts and, above all, present the video showing how well she had created a respectable imagery of her 'boy' for future remembrance.

Being constructed as part of an extended family, hairdressers are subjected to the way in which extended family should be treated from a Pentecostal perspective; i.e. supervision and a critical control of responsibilities on the part of the Pentecostal owner. Whereas on the one hand the social and cultural obligation exists to be responsible, Pentecostalism at the same time allows for the moral and spiritual legitimacy to be both in control ('on top of things' as the owners say) and distant at the same time. One important element in this distancing rhetoric of Pentecostalism is the extensive emphasis on the nuclear family, while the extended family is proclaimed a liability (Mate 2002, Van Dijk 2004). Believers are usually bombarded with messages that inform them about being careful with their relations with the extended 
family, cutting obligations and relations of reciprocity as much as they can, or at least bringing reciprocal relations under extensive moral and spiritual control and scrutiny (Meyer 2002, Van Dijk 2002, Prince 2007). Accepting gifts from relatives beyond the confines of the nuclear family and giving gifts to distant family members is considered to be playing with fire (Van Dijk 2005). Emphasising the peril in such reciprocal relatedness, the widespread notion that what the Devil gives 'can never be trusted' makes people aware that the giving or receiving of gifts is never neutral as it may harbour spiritual entities that are demonic.

The effect of cutting ties with the extended family has profound ramifications at many different levels. Pentecostals cannot readily commit themselves to the performance of all sorts of family-related customary rituals, such as those that take place in the context of birth and death, name-giving and marriages. Careful supervision should take place and the pouring of libations to the family ancestors, for example, are prohibited.

While one might think this is mere ideology, in practice even Pentecostals cannot be seen to be insensitive to the demands, obligations or needs of the extended family. The fact of the matter is that at home and in the diaspora, explicit 'teaching' takes place for Pentecostals on how to cut these ties. This severing of ties is expected in the context of marriage, funerals or name-giving ceremonies. Pentecostal teachings deal with how to withstand pressure from elder relatives, as well as to arrange one's affairs to ensure that gifts are directed towards the church and God's cause instead of meeting the needs of the family. In addition to the Bible classes and counselling sessions where all of this is discussed between pastors and members, there is also an extensive literature to inform Pentecostal members of the same. Here the nuclear family of the leading pastor is often portrayed as a shining role model of how social life should be organised, maintained and supervised. The imagery of the modern believer being in control of his/her situation, planning for the future and struggling against uncontrollable demands on family resources is a finely tuned but highly effective message. Obligations are translated as risks that 'may destroy your family' as one of the Gaborone-based pastors preached. There is upfront training in distancing at almost every level of involvement in the church, Pentecostal ideology and everyday life.

This Pentecostal ideology strengthens the owners' responsibility for employees from Ghana, the obligation to incorporate them in a widely defined kinship pattern as 'sons and daughters', while making sure that 
their needs are controlled in a way that may not affect the owner's resources. In spite of the kinship idiom, there is not usually a friendly or convivial relationship between personnel recruited in Ghana and the owners, and sometimes distrust prevails. Beyond owners' claims that their workers are 'lazy' or 'cheating' them, owners sometimes go as far as checking out the houses where workers live to see whether or not the workers are taking customers away from the shop by cutting their hair in their own homes. 'Family' is a liability and is not to be trusted, and complaints by workers usually go ignored. Although Kofi complained repeatedly and bitterly about the dangerous working conditions in his hair salon and the poor living conditions in the place where he was staying (and which had been arranged by the owner), the owner turned a deaf ear to his complaints. They were received much in the same way as Pentecostals are 'trained' to receive calls for help and attention from the extended family. This is informed by an awareness of the dangers and perils of reciprocity and of extending obligations beyond the confines of the nuclear family (Van Dijk 2002, 2005). The owner did not do much about his complaints; gloves were not provided.

\section{'We have to teach them'}

An additional factor in understanding the social distancing on the part of owners is the relatively late arrival of HIV/AIDS in Ghanaian society. Most owners had left Ghana for Botswana before AIDS became a serious issue. Overall, the HIV/AIDS infection rate in Ghana is much lower than in Botswana, meaning that it is the hairdressers more than the owners who find themselves in a position where they are confronted with the seriousness of the issue. Ghanaian hairdressers tend to use the local shampoo girls as a kind of shield or go-between between themselves and the customer (Van Dijk 2003). If shampoo girls find wounds, sores or scars on a customer's head, they are the first to deal with this situation of potential danger as well as the embarrassment of asking the customers 'to come back another time'. This is tricky in the sense that every customer is a source of income in a highly competitive market and they may decide never to come back. Embarrassment must be avoided at all costs. Owners look sharply and critically into this because of the percentage system: a substantial part of their income is dependent on maintaining a happy clientele. Hairdressers may have no other option than to deal with the head and hair of a person who 
could be infected, often dealing with hair styles that require lengthy, intense and repeated contact with the head and skin.

In a context of marked competition, gloves are a tricky issue. They may signal, embarrassingly for all to see, that something is wrong with the head and the skin of a particular customer, that there is something that the hairdresser does not trust. Customers can be explicit about not wanting to be treated with gloves, with 'rubber' as some would say, to avoid any public embarrassment. What Erasmus (2000) has called 'hair politics' becomes in fact a politics of touching in the face of a liberal, competitive market where the fight for the customer is based on hard economics. Kofi never touched his customers with gloves because he suspected the reason for the owner not providing him with the items was that the limited market in one of the poorer areas in town where his salon was located required 'real touching'. The use of gloves would have meant even fewer customers and hence less income. Similar negotiations of the use of 'rubber' in the context of a competitive market have been noted in the use of condoms by sex workers, for instance in the large cities of Malawi (see van den Borne 2005). Yet, unlike the condom, the glove does not seem to produce the kind of moral antagonisms that the large-scale introduction of the condom has brought about in Christian circles in the past, condemning it as providing a license for 'sexual promiscuity' (Taylor 1990, Amanze 2000, Pfeiffer 2004, Geissler and Prince 2007).

Discussing this issue with salon owners revealed that notions of superiority surfaced again in how they perceived HIV/AIDS as requiring them to maintain social distance. Often the answer given was 'we have to teach them', by which they meant that they have to sit down with the customer and explain the use of the glove if he/she has a problem with their use. 'You see,' one owner explained, 'we can teach them how to take care of their skull if we discover wounds and soars. We tell them they should apply Mercy Cream (a disinfectant cosmetic product that is imported from Ghana, RvD) and then we send them home and tell them to come back a week later!' In actual fact, some of the hairdressers told me, this hardly ever happens as the owners are not that much involved on a daily basis with what goes on in the direct contact between the worker and the customer. As these hairdressers would say; 'we are told to use gloves at all times. Customers cannot say "no" and the owners tell us we should educate them!' Hence the use of gloves, irrespective of the actual reality of their usage, is enveloped 
in a discourse that places the owners in the superior position of being able to teach their workers and customers what is right, what is proper bodily care and how to negotiate the dangers of infection. At the same time, they ambiguously neither provide gloves nor enforce their use.

This discourse on teaching ties in with the ideas the shop owners have of the moral status of their host society. There is a strong sense of the moral inferiority of Botswana society vis-à-vis their own Ghanaian 'character', of which the current AIDS crisis, in their view, is both a symptom and proof. The promiscuity - the 'jolling that men in this society' do - is strange to their Ghanaian 'nature' and their Christian morality, and a threat to the status and behaviour of their own men and husbands. Their disregard for the moral status of Botswana society goes as far as discouraging their own children from developing friendships with local age mates and attempting to ensure that relationships only develop with partners from Ghana. Control over the salon is rarely relinquished to 'locals', as the owners instead prefer to recruit such personnel and caretakers from Ghana. There is little confidence in local employees, who are often perceived as stealing and cheating, as slow learners and unreliable when it comes to keeping time.

These anti-Botswana sentiments are not only encouraged by the government's policies of localisation that jeopardise the position of foreigners and their businesses but are also strengthened by the AIDS crisis. The fact that Ghana and the Ghanaian community are less affected by AIDS is perceived as a consequence of their higher moral status and 'superior character'. Knowing all too well that the most important way by which HIV/AIDS is spread is through heterosexual and unsafe sexual relations, the businesses they run have a moral flipside that does not confirm and even contradicts the higher ground the female owners wish to occupy. On the one hand, owners want to make it clear that in the businesses they run they are dealing with what they perceive as the ignorance of the local population in terms of the skills in doing hair, the treatment of body hygiene and care, and the handling of money and business affairs. In addition, this superiority also needs to transpire in dealing with the spiritual aspects of being placed in a competitive market.

There is an easy slippage in the manner in which teaching hair, beautification and body care relates to notions of how to teach proper prayers and spiritual protection. The salon owners receive spiritual protection through Pentecostal prayers and deliverance because they 
stick, in their view, to a higher morality of conduct and a superior faith. Many stories circulate among owners of how their businesses came under attack spiritually, through the actions of envious competitors. Hair can be taken from the salon to do magic tricks on the owners, something they would refer to by using the Setswana vernacular muti. In some cases, owners explained how they had to fire some of their local workers because of the magic tricks they had been playing on the business, out of spite and jealousy. Hence reading the Bible while in the shop and 'teaching our customers about the Bible while they sit in our chairs' is part of an overall idea of how the superiority of the 'blood of Jesus' can be brought to bear in how AIDS and evil spirits can be held at a safe distance from the salon and its owner.

The paradox is that the salon and the business of doing hair is about enhancing a woman's attractiveness, about sexuality, and indeed about competitiveness that is likely to cause envy and jealousy. As a Motswana journalist B. Seleke described in a recent newspaper article 'The Forbidden Pleasure' (The Echo, 7 June 2007):

The last shampooing was followed by a very gentle, very relaxing, highly sensual head massage that we only wish for but cannot really afford. The problem: I was in a public hair salon (one of the Ghanaian owned hair salons in the African Mall in Gaborone, $\mathrm{RvD}$ ) and the massage came from a stranger....

The thing is she had been washing my hair while I was dead quiet because you cannot really compete with all the activity on your head, then suddenly it went quiet and all that was left were gentle hands swirling around on my head. That was really nice, but it was also quite embarrassing. It felt like I was enjoying the forbidden fruit of something, it felt obscene especially since it was from a strange girl.

The salon owners make a profit from something they claim to distrust or to be concerned about as being part of a morally inferior society or way of conduct. This is precisely why Pentecostalism and its moral and ideological messages are so important to these owners. They help to resolve this paradox whereby the ambition of taking the higher moral ground is potentially undermined by the nature of the business they are in. Pentecostal leaders educate their people too about style, consumption, beautification and the like but much as they emphasise success and prosperity in these matters, they also impart to their members that all of this should not run wild. Their message is one of control so that the demons of consumption, money, beauty and sexuality do not take possession of the person but that the person remains in control of 
these matters. It is on the basis of these teachings that owners talk of the 'character' they show by dealing with the body and its beautification while controlling, customising and tailoring its public appearance. Many discussions are devoted to 'what is being over the top', or where a certain style 'went too far' as a true middle-class positioning is about knowing and understanding such limits of decency, appropriate style and dressing.

Pentecostal churches further support the salon owners' notion that their middle-class position entails the control of social relations - to the extent of rupturing them - through training, teaching and education. Pentecostal practices involve a range of fasting rituals in which so-called 'dry fasting' (no food or water) is perceived as the most important and the most effective form of 'pleasing God' by controlling one's body and one's metabolism. By controlling bodily needs, total concentration on heavenly powers is aimed for. The belly is considered the seat of ancestral powers that can be controlled by fasting. Fasting can change one's circumstances and provoke a breakthrough in situations that bind a person and keep him or her under the control of the ancestral powers. It is for this reason that owners regularly fast in the hope that fortune will be maintained and heavenly powers will provide success and prosperity.

HIV/AIDS has not become much the focus of Pentecostal fellowship activities, although most of the churches subscribe to abstinence campaigns (however unrealistic this may be in the highly urbanised environment of Gaborone). These abstinence campaigns feed into and support the desensitising paradigm crucial to Pentecostal practice. Abstinence confirms the overall idea that a true and genuine Pentecostal believer is indeed capable of controlling his/her social relations; s/he is a modern individual to whom sexual lust represents just another demon that must be controlled instead of letting it control oneself. ${ }^{3}$ In the Ghanaian context it is the image of Mami Wata that is iconic of what Pentecostals have in mind: the marine spirit, half-woman halffish, which seduces men into relationships and takes its victims to her marvellous treasures under the sea in exchange for one's soul.

\footnotetext{
3 This is particularly the case with masturbation, which is perceived as another forceful demon the Pentecostal believer should be able to cast out. Pastors are approached by men who seek help in this regard as this demon appears hard to deal with.
} 
In this context, the controversy about gloves demonstrates how a notion of middle-class superiority in teaching a society how to behave, how to control life and to be aware of certain dangers, spiritually and morally, removes itself from everyday practices. While providing education often enveloped in Pentecostal style and moral rhetoric, some owners do not supply gloves irrespective of maintaining and presenting a Pentecostal image of themselves. The question is how the contradiction between owners underscoring how the person from a Pentecostal perspective should be in control of bodily style and spiritual powers while ignoring or denying these controls to their workers can be interpreted. How can they reconcile being interested in educating their workers and customers, while they keep a social distance and turn a deaf ear to the complaints of their workers at the same time?

\section{Matters of choice}

It would be erroneous to see Pentecostal ideology as being prescriptive. In the emerging literature on the relationship between Pentecostalism and AIDS, there is a tendency to view Pentecostal messages as prescribing social behaviour (abstinence, being faithful to one partner) leading to an actual performance of that behaviour (see Dilger 2007, Mate 2002, Garner 2000). This leads to some conclusions about how Pentecostals display more AIDS-awareness behaviour and therefore less risky behaviour patterns compared to non-believers or other faiths. Garner (2000) tellingly entitled his article on the subject matter 'Safe sects'. Yet in many cases, such a direct and causal relationship between a prescriptive ideology and observable behaviour remains to be proven, as the prescriptive factor cannot be teased out of all that made people change their conduct (Prince 2007).

While the prescriptive nature of Pentecostal ideology is problematic, I was struck by the extent to which a notion of having to 'educate' people did not seem to imply expectations of any automatic change in behaviour at all. Interestingly, the notion of being in control of one's life was more about being aware and being made to be aware of options and choices that lay ahead than of really implementing other behavioural styles. Certainly, in the Ghanaian understanding of becoming a born-again Pentecostal, there is the notion that this is about choice; is the person interested in becoming a convert prepared to 'take Jesus', in local parlance fa Fesu. This expression me fa Fesu (I have taken Jesus) 
means that the convert has made a conscious decision to join the Pentecostal faith. Pentecostalism raises awareness of the conscious choices that have to be made; about which customary or traditional cultural rituals to follow, which places to visit, which relationships to engage in. And even choices are implied about whether one should be delivered and have a breakthrough in a certain matter or whether demonic forces need to be suspected and any wealth is genuine and uncontaminated by ancestral curses. Pentecostalism is a realm of choices and choicemaking in which guidance, advice, competence, skills and training become critical, but where choice-making instead of superimposition is strongly maintained. There is no sense that one can become a Pentecostal Christian by birth as the moment of becoming born-again is considered the ultimate moment of 'giving one's life to Christ'. The Pentecostal ideology and practice suggests a notion of the victory of choice over cultural conditions and prescriptions.

A great deal of emphasis is placed in sermons, prayers and deliverance on participation in the domain of entrepreneurial activity on the market as a domain where choice can be played out proactively. This amounts to a spirit of entrepreneurialism. Migrants are not expected to sit and wait for things to come their way, they are told not to adopt a begging attitude and are made aware of the fact that they can take control of their success and prosperity. Moreover, there is little support for those that do not seem to take initiatives. The dictum here is that 'there is help for those who help themselves'.

Much of this market ideology transpires in the role-modelling performed by the church leaders themselves. The leaders can be interpreted as being experts in type-branding their charisma in such a way that it almost becomes a distinct commodity on a religious market (see Smith 2001, Hasu 2006, De Witte 2008). These leaders do not perceive of risk and challenge as anything negative per se, but regard it as the ultimate litmus test for divine and benevolent grace. After all, those who harbour the Godly sent powers will survive; those who are not under such benevolent inspiration are likely to perish.

For the workers in hair salons, the glove indicates a more negative notion of choice. The owners can exercise the choice not to care about gloves or consider their use from a strategic perspective when it comes to how to attract or keep customers. While the owners are encouraged by Pentecostal ideology to become proactive by taking on the challenges that the local market has to offer, some of the real challenges and risks are left for their workers, allowing them little room to act. In 
the context of AIDS, the presence or absence of gloves thus indicates different class positions in the challenges and risks that owners and workers are either engaging in or facing.

The issue of gloves and the way in which they signal antagonistic economic power relations are usually not the manner in which their presence or absence in the context of AIDS is being discussed in the literature. Studies from the Southern African region suggest that the glove has become contested in connection with the politics of care (e.g. Henderson 2004; Lindsey et al. 2003). Gloves represent a de-humanisation of the AIDS sufferer as the glove comes to stand between the caregiver and the person suffering from AIDS and may even represent a withdrawal of care altogether in the pursuit of creating sanitised conditions in which chances of infection are minimised. Western-trained nurses would advise caregivers 'to wear three pairs of gloves in handling patients' (Henderson 2004: 48), an option which caregivers (usually a patient's relatives) find disheartening and difficult to follow. Lindsey et al. (2003: 495) write:

Although the caregivers were advised on the use of universal precautions, very few caregivers heeded this advice. As one caregiver explained, 'It is my daughter, I love her. I can't wear gloves or other things. If I am holding or nursing my child I love, putting a barrier would be like I don't love her.

Henderson (2004: 48) expands this by showing how special apologies and legitimacy have to be created to avoid flesh-to-flesh contact in a way that would usually have been normal and signal sensitivity:

She (the caregiver, $\mathrm{RvD}$ ) told Nkosinathi (the patient, $\mathrm{RvD}$ ) that he should not be unhappy in her request to now use gloves to wash him. It was not that she did not love him or that she found him offensive; wearing gloves was to protect herself from the virus. The word she used in Zulu to refer to the fact that she did not find him offensive is a powerful one, ukunyanya. Ukunyanya connotes disgust or loathing and suggest uncontrollable and visceral responses to areas of life.

AIDS brings into relief a politics of care in which the object of the glove becomes an index for the complexities around contact and status positions. In the case of salon owners and hairdressers, gloves may be absent because of the economies of the market and competition, while in the case of the caregivers the gloves may be absent because of the economy of affect in a context of affliction. Hence, the use or non-use of the glove indicates different positions and constraints for withdrawing 
contact and creating social distance. The absence of gloves in the case of caregivers can be regarded as meeting social and cultural approval because it signals a stance against such distancing, the wilful and deliberate abrogation of affectionate human contact. The absence of gloves in the case of the hairdressers indicates an apparent distance on the part of owners to the fate of their workers as economic interests are more important and they do not want to hurt the feelings of their clientele. There is a clear and conscious reflection of the significance of objects regarding the mapping and marking of where social distancing occurs, can be permitted or should be abhorred.

In the context of AIDS, the use or non-use of gloves has become an important consideration and a clear matter of making choices and being aware of the implications and consequences of such choices in terms of human affection or of economic interests. Interestingly, on the part of the owners, Pentecostalism does not 'automatically' relate to care, to the provisioning of care or of a social prescription towards taking care of the interests of their personnel. Instead, the issue of the glove indicates the limits of the faith's capacity to prescribe certain styles of behaviour, also indicating how careful social science must be in linking religion to the provisioning of social security (see De Bruijn \& Van Dijk (forthc.) for a critical discussion). While the Ghanaian Pentecostal churches in Gaborone organise Bible classes, counselling sessions and AIDS-awareness services for its membership and is involved in certain faith-based organisations (FBOs) that organise education, the glove makes it painfully clear how far an idea of social care actually stretches. In fact, the opposite, namely that of social distancing, appears to be emphasised in the way Pentecostal ideology makes its influence felt.

\section{Conclusion and interpretation}

In a recent critique of the anthropology of Christianity, Robbins (2007) argued that a major obstacle preventing this field from developing has been that anthropology has persistently emphasised continuity over discontinuity and change (see also Engelke 2004, Hann 2007). Believers' own understandings of the meaning and significance of rupture is thereby often reasoned away and re-interpreted as part of a broader stream of cultural change. In studying Pentecostal interaction with everyday living and working practices of hair salon owners, their involvement with the faith and an AIDS-infected society, the present article 
has indicated one domain in which discontinuities can be explored. The glove allows us to explore how a Christian faith informs or legitimises fractures in the social by what I have called 'social distancing'. There is a host of literature on Pentecostalism, also in the context of the study of AIDS, that emphasises the notions of 'care' and 'security'. Ultimately, these studies argue, despite the Pentecostal emphasis on breaking with the past, Pentecostalism proves 'good' to society, for instance by prescribing behavioural change (see Garner 2000, Dilger 2007, Amanze 2000, Hofer 2003, Swart 2006) or delivering counselling, healing or other forms of care. This line of interpretation places faith in the service of reproducing society and thus socio-cultural continuity.

At the same time, by exploring the particular case of Pentecostalism in the Ghanaian community in Botswana, we need to acknowledge that in addition to the care and prescriptions of behavioural change it provides, the faith does carry notions of discontinuity, disruption and social distancing too. At an ideological level, the faith's practices are not inspired by a desire to reproduce anything from a cultural past, from what is considered traditional, primordial or cherished historical forms of religious belief and practice. It also provides legitimacy to the breaking of social relations in the present, and allows for a limitation or abrogation of a sense of community outside Pentecostal circles. As this translates into practices of social distancing, we notice how it may involve class interests, produce indifference, negate loss and suffering and cause engagements with risk and danger (and therefore does not produce security at all times!) as is evident in the wilful absence of protective gloves. Similar to conversion and claims of radical personal change, these elements of Pentecostalism cannot and should not be explained away by anthropology by pointing at other and supposedly more relevant motivations, such as personal economic gain. While the absence of gloves may indeed be motivated by economic rationalities, as the workers in the hair salons indicate, this chapter has argued that ideological motivation and inspiration must be given a place too in why and how such risks and insecurities are deliberately engaged in by wealthy middle-class salon owners. Social distancing produces not merely stability but risk and vulnerability too. While AIDS is destroying the social life in countries such as Botswana, anthropology must allow for the reality of a Pentecostal model of engagement in which an ideology of discontinuity is translated into practices of rupture and social distancing. Faith inspires, in the context explored in this chapter, a culture of discontinuity not only at an ideological level but in its 
praxis as well, particularly in the way it is incorporated in the marking of class positions.

\section{References}

Akoko, R. M. 2004. 'From Asceticism to a Gospel of Prosperity. The case of the Full Gospel Mission in Cameroon.' Fournal for the Study of Religion, vol. 17, no. 4, pp. 47-66.

Amanze, J. N. 2000. 'Covenant with Death. The attitude of churches in Botswana towards the use of condoms by Christians, and its social implications.' Botswana Notes and Records, vol. 32, pp. 201-208.

Asad, T. 1993. Genealogies of Religion. Discipline and Reasons of Power in Christianity and Islam. Baltimore and London, John Hopkins University Press.

Chidester, D. 1992. Word and Light. Seeing, Hearing and Religious Discourse. Urbana, University of Illinois Press.

- 2005. 'The American Touch. Tactile Imagery in American Religion and Politics.' In: C. Classen (ed.) The Book of Touch. Oxford, Berg Publishers.

Coleman, S. 2004. 'The Charismatic Gift.' Fournal of the royal Anthropological Institute, vol. 10, no. 2, pp. 421-442.

De Bruijn, M. \& Van Dijk, R. Forthc. 'Questioning Social Security in the Study of Religion in Africa: The Ambiguous Meaning of the Gift in African Pentecostalism and Islam.' In: C. Leutloff-Grandits, A. Peleikis and T. Thelen (eds.) Social Security in Religious Networks. Anthropological Perspectives on New Risks and Ambivalences. Oxford, Berghahn.

De Witte, M. 2003. 'Money and Death. Funeral Business in Asante, Ghana', Africa, vol. 73, no. 4, pp. 531-59.

- 2008. Spirit Media. Charismatics, Traditionalists and Mediation Practices in Ghana. Ph.D.-diss. Univ of Amsterdam.

Dilger, H. 2007. 'Healing the Wounds of Modernity. Salvation, Community and Care in a Neo-Pentecostal Church in Dar Es Salaam, Tanzania.' Fournal of Religion in Africa, vol. 37, no. 1, pp. 59-83.

Engelke, M. 2004. 'Discontinuity and the discourse of conversion.' Fournal of Religion in Africa, vol. 34, no. 1/2, pp. 82-109.

Erasmus, Z. 2000. 'Hair Politics.' In: S. Nutall \& C. A. Michael (eds.) Senses of Culture. South African Culture Studies. Oxford, Oxford University Press.

Feldman, A. 1994. 'On Cultural Anaesthesia. From Desert Storm to Rodney King.' American Ethnologist, vol. 21, no. 2, pp. 404-418.

Garner, R. C. 2000. 'Safe Sects? Dynamic Religion and Aids in South Africa.' Fournal of Modern African Studies, vol. 38, no. 1, pp. 41-69.

Geissler, P. W. \& Prince, R. J. 'Life Seen: touch and vision in the making of sex in Western Kenya.' Journal of Eastern African Studies, vol. 1, no. 1, pp. 123-149.

Geurts, K. L. Culture and the Senses. Bodily ways of knowing in an African community. Berkeley, Univ. of California Press.

Gifford, P. 2004. Ghana's New Christianity. Pentecostalism in a Globalising African Economy. London, Hurst.

Hann, Ch. 2007. 'The Anthropology of Christianity per se.' European Fournal of Sociology, vol. XLVIII, no. 3, pp. 383-410.

Hasu, P. 2006. 'World Bank \& Heavenly Bank in poverty and prosperity. The case of the Tanzanian Faith Gospel.' Review of African Political Economy, vol. 33, no. 110, pp. 679-692. 
Henderson, P. C. 2004. 'The Vertiginous Body and Social Metamorphosis in a Context of HIV/AIDS.' Anthropology Southern Africa, vol. 27, no. 1\&2, pp. 43-53.

Herzfeld, M. 1992. The Social Production of Indifference. Exploring the Symbolic Roots of Western Bureaucracy. Chicago, University of Chicago Press.

Hofer, K. 2003. 'The Role of Evangelical NGOs in International Development. A comparative case study of Kenya and Uganda.' Afrika Spectrum, vol. 38, no. 3, pp. 375-398.

Lindsey, E., Hirschfeld, M., Tlou, S. \& Ncube, E. 2003. 'Home-based Care in Botswana: Experiences of Older Women and Young Girls.' Health Care for Women International, vol. 24, pp. 486-501.

Marshall-Fratani, R. 2000. 'Mediating the global and local in Nigerian Pentecostalism.' In: A. Corten \& R. Marshall-Fratani (eds.), Between Babel and Pentecost. Transnational Pentecostalism in Africa and Latin America. London / Bloomington (IN), Hurst Publishers / Indiana University Press

Martin, D. 1990. Tongues of Fire. The Explosion of Protestantism in Latin America. Oxford, Basil Blackwell.

Mate, R. 2002. 'Wombs as God's Laboratories. Pentecostal Discourse of Femininity in Zimbabwe.' Africa, vol. 72, no. 4, pp. 549-568.

Maxwell, D. 1998. "'Delivered from the spirit of poverty?": Pentecostalism, prosperity and modernity in Zimbabwe.' Journal of Religion in Africa, vol. 28, no. 3, pp. 350-373.

Meyer, B. 1998. " Make a Complete Break with the Past”. Time and Modernity in Ghanaian Pentecostalist Discourse.' In: R. P. Werbner (Ed.), Memory and the Postcolony. Postcolonial Identities Series. London: Zed Books.

—. 2002. 'Pentecostalism, prosperity and popular cinema in Ghana.' Culture and Religion, vol. 3, no. 1, pp. 67-87.

—. 2004. 'Christianity in Africa: from African Independent to Pentecostal-Charismatic Churches.' Annual Review of Anthropology, vol. 33, pp. 447-474.

—. 2006. Religious Sensations. Why Media, Aesthetics and Power Matter in the Study of Contemporary Religion. Inaugural Lecture, Free University, Amsterdam, 6 October, 2006.

Nyamnjoh, F. B., Durham, D., and Fokwang, J. D. 2002. 'The domestication of hair and modernised consciousness in Cameroon: a critique in the context of globalisation.' Identity, Culture and Politics, vol. 3, no. 2, pp. 98-124.

Ossman, S. 2002. Three Faces of Beauty. Casablanca, Paris, Cairo. Durham, Duke University Press.

Pfeiffer, J. 2004. 'Condom Social Marketing, Pentecostalism, and Structural Adjustment in Mozambique. A clash of AIDS prevention messages.' Medical Anthropology Quarterly, vol. 18 , no. 1 , pp. $77-103$.

Prince, R. J. 2007. 'Salvation and Tradition: Configurations of Faith in a Time of Death.' Fournal of Religion in Africa, vol. 37, no. 1, pp. 84-115.

Robbins, J. 2004. 'The Globalization of Pentecostal and Charismatic Christianity.' Annual Review of Anthropology, vol. 33, pp. 117-143.

- 2007. 'Continuity Thinking and the Problem of Christian Culture. Belief, Time, and the Anthropology of Christianity.' Current Anthropology, vol. 48, no. 1, pp. 5-38.

Seremetakis, N. (ed.) 1994. The Senses Still. Perception and Memory as Material Culture in Modernity. Chicago, University of Chicago Press.

Smith, D. J. 2001. "The Arrow of God". Pentecostalism, Inequality, and the Supernatural in South-Eastern Nigeria.' Africa, vol. 71, no. 4, pp. 587-613.

Stoller, P. The Taste of Ethnographic Things. The Senses in Anthropology. Philadelphia, University of Philadelphia Press.

Swart, I. 2006. 'Churches as a stock of social capital for promoting social development in Western Cape communities.' Journal of Religion in Africa, vol. 36, no. 3/4, pp. 346-378. 
Taylor, C. C. 1990. 'Condoms and Cosmology. The 'fractal' person and sexual risk in Rwanda.' Social Science and Medicine, vol. 31, no. 9, pp. 1023-1028.

Van Dijk, R. 1992. 'Young Puritan Preachers in Post-independence Malawi.' Africa, vol. 62, no. 2, pp. 159-181.

- 1997. 'From Camp to Encompassment: Discourses of Transsubjectivity in the Ghanaian Pentecostal Diaspora'. Fournal of Religion in Africa, vol. 27, no. 2, pp. 135-169.

. 1998. 'Pentecostalism, Cultural Memory and the State. Contested Representations of Time in Postcolonial Malawi.' In: R. Werbner (ed.) Memory and the Postcolony. African Anthropology and the Critique of Power. London, Zed Books.

—. 2002. 'Religion, Reciprocity and Restructuring Family Responsibility in the Ghanaian Pentecostal Diaspora.' In: D. Bryceson \& U. Vuorela, (Eds.) The Transnational Family. New European Frontiers and Global Networks. Oxford, Berg.

- 2003. 'Localisation, Ghanaian Pentecostalism and the Stranger's Beauty in Botswana.' Africa vol. 73, no. 4, pp. 560-583.

- 2004. 'Negotiating Marriage: Questions of Morality and Legitimacy in the Ghanaian Pentecostal Diaspora.' In: R. van Dijk \& G. Sabar (Eds.) Uncivic Religion: African Religious Communities and their Quest for Public Legitimacy in the Diaspora, Fournal of Religion in Africa, Thematic Issue, vol. 34, no. 4, pp. 438-467.

- 2005. 'The Moral Life of the Gift in Ghanaian Pentecostal Churches in the Diaspora. Questions of (in-)dividuality and (in-)alienability in Transcultural Reciprocal Relations', in Commodification, Things, Agency, and Identities. The Social Life of Things Revisited, eds W. M. J. van Binsbergen and P. L. Geschiere, Munster: Lit-Verlag.

- 2007. 'The Safe and Suffering Body in Transnational Ghanaian Pentecostalism: Towards an Anthropology of Vulnerable Agency.' In: M. De Bruijn, R. van Dijk and J. B. Gewald (Eds.), Strength Beyond Structure. African Dynamics Series. Leiden: Brill. Verrips, J. 2006. 'Aisthesis and An-aesthesia.' Ethnologia Europaea, vol. 35, no. 1/2, pp. $27-33$.

Weiss, B. 2005. 'Consciousness, affliction \& alterity in urban East Africa.' In: A. Honwana \& F. de Boeck (eds.) Makers $\mathcal{E}^{2}$ Breakers: children $\mathcal{E}^{2}$ youth in postcolonial Africa. Oxford, James Currey. 